\title{
MISCARRIAGES AND ITS RELATIONSHIP WITH DEPRESSION \& QUALITY OF LIFE: A COMPARATIVE STUDY
}

Parvasha Memon ${ }^{\mathrm{a}}$, Lubna Ahmed Soomro ${ }^{\mathrm{b}}$, Muniza Malik ${ }^{\mathrm{b}}$, Saira Almas ${ }^{\mathrm{c}}$

aLecturer, Department of Psychology, University of Sindh, Jamshoro.

${ }^{\mathrm{b} A s s i s t a n t}$ Professor, Department of Psychology University of Sindh, Jamshoro.

'Post-Graduate Trainee, Department of Gynae \& Obstetrics Dow University of Medical and Health Sciences Karachi, Sindh.

\section{ABSTRACT:}

BACKGROUND \& OBJECTIVE: Quality of life describes the way of perception of an individual's position in life. The objective of this study was to assess the impact of miscarriages on quality of life and depression in women with or without miscarriages.

METHODOLOGY: Descriptive Cross sectional study was conducted at different hospitals of Hyderabad, Sindh in six months among 200 participants (100 without miscarriage \& 100 with miscarriages). The age range of the participants was 18-40 years. Demographic information was taken to get information about the participants like age, family system, education. Two validated, structured questionnaire namely; Quality of Life (QOL) and Beck Depression Inventory (BDI) were administered. Data was analyzed by SPSS version 23.0, independent sample t-test was applied to observe difference of depression and quality of life among women with or without miscarriages.

RESULTS: In the sample among women with miscarriages $42 \%$ were in the age range of 18-30 years and $58 \%$ were of age $31-40$ years. Among females without miscarriages $63 \%$ were aged 18 30 years and $37 \%$ were $31-40$ years. Females without miscarriages have education up to masters $(20 \%)$ and graduation (23\%) and most females with miscarriages have primary education (38\%). The independent sample mean differences revealed females with miscarriages more depressive ( $t$ $=24.407, \mathrm{p}<0.05$ ) than females without miscarriages (women without miscarriage $=27.52 \pm$ 5.43; women with miscarriage $=8.08 \pm 5.82$ ). Females with miscarriages feel hopeless $73.3 \%$, guilty $70.3 \%$, highly self-blaming 68.3 , and have feeling of complete failure $88.1 \% .98 \%$ females reported that they don't cry even they want to, on the other hand only $3 \%$ females without miscarriages reported this feeling. The perceived quality of life is higher in women without miscarriages $(t=11.75, p=.000), 58.1 \%$ females with miscarriages have emotional problems, feeling nervous $59.4 \%$ and lack of cheerfulness $63.8 \%$.

CONCLUSION: Depression is increasing rapidly in the women that loss their fetus. They feel high sadness, grief and low quality of life as compared to women without miscarriages.

KEYWORDS: Quality of life, Depression, Miscarriages, Abortion.

How to cite this:

Doi: https://doi.org/10.37723/jumdc.v11i4.439

Memon P, Soomro LA, Malik M, Almas S. The Impact of Miscarriages on Quality of Life and Depression: A Comparative Analysis of Women with or without Miscarriages. JUMDC. $2020 ; 11(4): 47-54$.

doi: https://doi.org/10.37723/jumdc.v11i4.439

This is an Open Access article distributed under the terms of the Creative Commons Attribution License (http://creativecommons.org/licenses/by/4.0), which permits unrestricted use, distribution, and reproduction in any medium, provided the original work is properly cited. 


\section{INTRODUCTION:}

Quality of life describes the way of perception of an individual's position in life. It reflects adjustment with cultural norms, values, and the way they use to achieve their goals and expectations ${ }^{[1]}$. According to Diagnostic and statistical manual-5 (DSM-V), depression is a neurotic disorder, that changes person's thinking and behavior. It interferes with an individual's normal life functioning and lack the ability to do work properly ${ }^{[2]}$. Depression is an abnormal condition that is caused by the three main dysfunctions in cognition. 1) the cognitive tried, in which an individual continues to think negatively, 2) negative self-schemas, in which an individual believes that he/she is a failure and loses hope for his betterment, 3) errors in logic, when the previous two conditions occur an individual stops thinking logically and continue to develop depressive symptoms ${ }^{[3]}$.

According to Maslow, depression is developed when the needs of an individual do not meet at any stage, especially self-actualization, because self-actualize individual have meaningful life and when this need do not meet then person starts to develop negative feelings or abnormal symptoms. Miscarriage is a natural process which results in fetus death. $10 \%-$ $20 \%$ of the pregnancy results in a premature miscarriage ${ }^{[4]}$. Miscarriages happen due to several reasons; hence most common cause is inherited abnormality or diabetes. Other causes are teratogens, drug abuse, and old age pregnancies ${ }^{[5]}$. Research has suggested that there is a relationship between quality of life and mental health of pregnant women with or without previous pregnancy loss. The findings show that the level of quality of life was low in those who had previous pregnancy loss while those who do not have any previous record of miscarriage. While those women who had previous miscarriages also have a decreased level of mental health than women without the history of miscarriages ${ }^{[6,7]}$. Furthermore, studies reveal that the women with miscarriages also suffer with the severe symptoms of depression ${ }^{[8]}$. They need more medical attention and care ${ }^{\text {[9] }}$. Findings of another study suggested that minor depression is same as major depressive disorder but does not meet the full criteria; it requires only two symptoms from the criteria to
Corresponding Author:

i Dr. Lubna Ahmed Soomro

Assistant Professor, Department of Psychology

University of Sindh, Jamshoro.

Email: melubna@hotmail.com

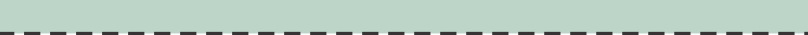

diagnose minor depression ${ }^{[10]}$. The findings clarify that the risk of depression is relatively high in the women with miscarriages ${ }^{[10,11]}$. Results of a study suggested that women with recent miscarriages show poor mental health and perceive low quality of life and feel insecure in their familial relationship but if social support provided to them their condition gets better ${ }^{[12,}$ ${ }^{13]}$.

Sigmund Freud and Karl Abraham first gave the psychodynamic explanation for depression. According to them there are many similarities between the people with clinically diagnosed depression and the people who lose their loved ones'. The symptoms compared were loss of appetite, disturbance in sleep, loss of interest in pleasurable activities and hopelessness. It gives rise to low self-esteem, and feelings of dependency upon others ${ }^{[14]}$.

According to Aaron Beck, an individual's thoughts, emotions and behaviors are correlated and have effects on one another. Beck gave three reasons that develop depression, 1) negative believes about one's own self; 2) errors in one's logic and 3) maladaptive attitudes. Depression produce negative beliefs about one-self, and future and world perceived as negative schemas. When a person develops the negative self-belief due to any loss or any kind of stressful event, he/she will emotionally feel distress and may behave aggressively ${ }^{[15]}$.

In terms of behavioral perspective, the behavior of a person is modified or shaped by the type of reinforcement or punishment they receive from environment. Gradually with time the rewards of life reduce, as some people find the other forms of rewards and continue with the normal life but few people cannot replace the type of reward once they have in life and they start to develop destructive behavior gradually ${ }^{[16,17]}$. Lewiston stated that there is a positive relation between the happiness, life satisfaction and the positive life rewards ${ }^{[14,15,16]}$.

The objectives are to examine the level of 
depression and quality of life in women with miscarriages compare with the women without miscarriages.

\section{METHODOLOGY:}

This descriptive cross-sectional study was conducted at various hospitals of Hyderabad, Sindh. Study participants were female of age group 18- 40 years, attending gynaecology outpatient clinic. They were divided into 2 groups; 100 females who previously had miscarriage and 100 female with no history of miscarriage. Participants were assured that their information would remain confidential and informed consent was obtained from all participants.

Data was collected by using 2 validated, structured questionnaires namely; Beck Depression Inventory (used to measure severity of depression) and Quality of Life (QOL)
Scale (used to measure physical functioning and emotional well-being). Duration of study was 6 months and convenient sampling technique was used. Females with previous mental health issues were excluded from the study.

Ethical Committee of Sindh University Jamshoro approved the study. Data was analyzed by using SPSS version 23. p-value less than 0.05 was considered statistically significant

\section{RESULTS:}

In our study $42 \%$ of women with miscarriages were in the age range of $18-30$ years and $58 \%$ were of age 31-40 years. Among females without miscarriages $63 \%$ were aged $18-30$ years and $37 \%$ were $31-40$ years.

Table-I: Demographic information of the participants.

\begin{tabular}{|c|c|c|}
\hline & $\begin{array}{c}\text { Women with } \\
\text { Miscarriages } \\
100\end{array}$ & $\begin{array}{c}\text { Women without } \\
\text { Miscarriages } \\
100\end{array}$ \\
\hline \multicolumn{3}{|l|}{ Age } \\
\hline $18-30$ years & 42 & 63 \\
\hline $31-40$ years & 58 & 37 \\
\hline \multicolumn{3}{|l|}{ Education } \\
\hline Primary & 38 & 21 \\
\hline Matriculation & 24 & 16 \\
\hline Intermediate & 15 & 20 \\
\hline Graduation & 13 & 23 \\
\hline Masters & 10 & 20 \\
\hline
\end{tabular}

Females without miscarriages had education up to masters $(20 \%)$ and graduation (23\%) while majority of females with miscarriages had primary education (38\%), matriculation (24\%), intermediate $(15 \%)$, graduation $(13 \%)$ and masters $(10 \%)$. 
Table-II: Comparison of depression among women with and without miscarriages (using Beck's Inventory).

\begin{tabular}{|c|c|c|c|c|c|c|c|c|}
\hline \multirow[t]{3}{*}{$\begin{array}{c}\text { Sleep or not } \\
\text { sleep as } \\
\text { usual }\end{array}$} & \multicolumn{2}{|c|}{$\begin{array}{c}\text { Can sleep as } \\
\text { usual }\end{array}$} & \multicolumn{2}{|c|}{$\begin{array}{c}\text { Don't sleep } \\
\text { well }\end{array}$} & \multicolumn{2}{|c|}{$\begin{array}{c}\text { Wake up 1-2 } \\
\text { hrs. earlier than } \\
\text { normal routine }\end{array}$} & \multicolumn{2}{|c|}{$\begin{array}{c}\text { Wake up several } \\
\text { hours earlier } \\
\text { than normal } \\
\text { routine }\end{array}$} \\
\hline & with & without & with & without & with & without & with & without \\
\hline & $1 \%$ & $36.4 \%$ & - & $60.6 \%$ & $33.7 \%$ & $2.0 \%$ & $65.3 \%$ & $1.0 \%$ \\
\hline \multirow{3}{*}{$\begin{array}{c}\text { Feel } \\
\text { discouraged } \\
\text { or not }\end{array}$} & \multicolumn{2}{|c|}{$\begin{array}{c}\text { Feel not } \\
\text { discouraged }\end{array}$} & \multicolumn{2}{|c|}{$\begin{array}{c}\text { Feel } \\
\text { discouraged }\end{array}$} & \multicolumn{2}{|c|}{$\begin{array}{c}\text { Feel much } \\
\text { discouraged }\end{array}$} & \multicolumn{2}{|c|}{ Feel hopeless } \\
\hline & with & without & with & without & with & without & with & without \\
\hline & - & $24.2 \%$ & - & $57.6 \%$ & $26.7 \%$ & $16.2 \%$ & $73.3 \%$ & $2.0 \%$ \\
\hline \multirow[t]{3}{*}{$\begin{array}{l}\text { Feel failure } \\
\text { or not failure }\end{array}$} & \multicolumn{2}{|c|}{$\begin{array}{l}\text { Not feel } \\
\text { failure }\end{array}$} & \multicolumn{2}{|c|}{ Feel Failure } & \multicolumn{2}{|c|}{$\begin{array}{l}\text { Feel lots of } \\
\text { failure }\end{array}$} & \multicolumn{2}{|c|}{$\begin{array}{c}\text { Feel complete } \\
\text { failure }\end{array}$} \\
\hline & with & without & with & without & with & without & with & without \\
\hline & - & $21.2 \%$ & - & $73.7 \%$ & $11.9 \%$ & $2.1 \%$ & $88.1 \%$ & $3.0 \%$ \\
\hline \multirow[t]{3}{*}{$\begin{array}{l}\text { Feel guilty or } \\
\text { not }\end{array}$} & \multicolumn{2}{|c|}{$\begin{array}{c}\text { Not feeling } \\
\text { guilty }\end{array}$} & \multicolumn{2}{|c|}{$\begin{array}{l}\text { Sometimes } \\
\text { feel guilty }\end{array}$} & \multicolumn{2}{|c|}{ Much feel guilty } & \multicolumn{2}{|c|}{$\begin{array}{l}\text { Complete feel } \\
\text { guilty }\end{array}$} \\
\hline & with & without & with & without & with & without & with & without \\
\hline & - & $54.4 \%$ & - & $42.2 \%$ & $29.7 \%$ & $1.0 \%$ & $70.3 \%$ & $2.0 \%$ \\
\hline \multirow{3}{*}{$\begin{array}{l}\text { Feel bad or } \\
\text { criticize } \\
\text { oneself for } \\
\text { everything } \\
\text { happened }\end{array}$} & \multicolumn{2}{|c|}{ Not feel bad } & \multicolumn{2}{|c|}{$\begin{array}{l}\text { Criticize } \\
\text { myself for } \\
\text { mistakes }\end{array}$} & \multicolumn{2}{|c|}{$\begin{array}{c}\text { Blame myself } \\
\text { for any }\end{array}$} & \multicolumn{2}{|c|}{$\begin{array}{l}\text { Blame myself } \\
\text { for everything } \\
\text { bad happened }\end{array}$} \\
\hline & with & without & with & without & with & without & with & without \\
\hline & - & $7.1 \%$ & - & $89.9 \%$ & $31.7 \%$ & $2.0 \%$ & $68.3 \%$ & $1.0 \%$ \\
\hline \multirow{3}{*}{$\begin{array}{c}\text { Cry or not cry } \\
\text { more than } \\
\text { usual }\end{array}$} & \multicolumn{2}{|c|}{ Not cry } & \multicolumn{2}{|c|}{$\begin{array}{l}\text { Cry more } \\
\text { than usual }\end{array}$} & \multicolumn{2}{|c|}{ Cry all time } & \multicolumn{2}{|c|}{$\begin{array}{c}\text { Not cry even } \\
\text { want to cry }\end{array}$} \\
\hline & with & without & with & without & with & without & with & without \\
\hline & - & $59.6 \%$ & - & $37.4 \%$ & $2.0 \%$ & - & $98 \%$ & $3 \%$ \\
\hline \multirow[t]{3}{*}{$\begin{array}{l}\text { Irritated } \\
\text { feelings }\end{array}$} & \multicolumn{2}{|c|}{ Not irritated } & \multicolumn{2}{|c|}{$\begin{array}{l}\text { Slightly } \\
\text { irritated }\end{array}$} & \multicolumn{2}{|c|}{$\begin{array}{l}\text { Irritated most } \\
\text { of the times }\end{array}$} & $\begin{array}{r}\begin{array}{r}\text { Feel irr } \\
\text { the }\end{array} \\
\end{array}$ & $\begin{array}{l}\text { ated all } \\
\text { ime }\end{array}$ \\
\hline & with & without & with & without & with & without & with & without \\
\hline & - & $61.6 \%$ & - & $35.4 \%$ & $1 \%$ & - & $99 \%$ & $3 \%$ \\
\hline
\end{tabular}

Majority of women with miscarriages in our study showed symptoms of major depression like feelings of hopelessness $(73.3 \%)$, feeling guilty $(70.3 \%)$, complete failure $(88.1 \%)$, sleep loss $(65.3 \%)$, irritated $(99 \%)$ and self-blaming $(68.3 \%)$. Nearly $98 \%$ females with miscarriages reported that they don't cry even they want to cry. On the other hand only $3 \%$ females without miscarriages reported this feeling. These findings indicate major depression among females with miscarriage.

The women with miscarriages have high score in depression $(27.52 \pm 5.43)$ than the women without miscarriages $(8.08 \pm 5.82)$. When independent sample mean differences for level of depression between women with miscarriages and without miscarriages was calculated ( $\mathrm{t}$-value $=$ $24.40, p=.000$ ), it was proved that women with recent miscarriages experience high depression due to the loss of their baby. 
Table III: Comparison of Quality of life among women with and without miscarriages.

\begin{tabular}{|c|c|c|c|c|c|}
\hline $\begin{array}{c}\text { Emotional problems } \\
\text { interfere with your social } \\
\text { activities of family and } \\
\text { friends }\end{array}$ & $\begin{array}{l}\text { Not at } \\
\text { all }\end{array}$ & slightly & $\begin{array}{l}\text { Moderately } \\
\text { severe }\end{array}$ & $\begin{array}{c}\text { Very } \\
\text { severe }\end{array}$ & Total \\
\hline women with miscarriage & $15.8 \%$ & $10.9 \%$ & $14.9 \%$ & $58.4 \%$ & $100 \%$ \\
\hline women without miscarriage & $53.5 \%$ & $17.2 \%$ & $5.1 \%$ & $24.2 \%$ & $100 \%$ \\
\hline $\begin{array}{c}\text { How much pain interfere } \\
\text { with your work? }\end{array}$ & Not at all & $\begin{array}{l}\text { A little } \\
\text { bit }\end{array}$ & Moderately & Extremely & Total \\
\hline women with miscarriage & $19.8 \%$ & $5.9 \%$ & $8.9 \%$ & $65.4 \%$ & $100 \%$ \\
\hline women without miscarriage & $57.6 \%$ & $13.1 \%$ & $7.1 \%$ & 22.2 & $100 \%$ \\
\hline $\begin{array}{l}\text { Have you been a nervous } \\
\text { person? }\end{array}$ & $\begin{array}{l}\text { Some of } \\
\text { the time }\end{array}$ & $\begin{array}{l}\text { Good bit } \\
\text { of the } \\
\text { time }\end{array}$ & $\begin{array}{l}\text { Most of the } \\
\text { time }\end{array}$ & $\begin{array}{l}\text { All of the } \\
\text { time }\end{array}$ & Total \\
\hline Women with miscarriage & 21.8 & $4.0 \%$ & $14.9 \%$ & $59.4 \%$ & $100 \%$ \\
\hline Women without miscarriage & $64.6 \%$ & $23.2 \%$ & $7.6 \%$ & $4.6 \%$ & $100 \%$ \\
\hline $\begin{array}{c}\text { Have you felt so down } \\
\text { that nothing could cheer } \\
\text { you up? }\end{array}$ & $\begin{array}{l}\text { None of } \\
\text { the time }\end{array}$ & $\begin{array}{c}\text { Bit of } \\
\text { the time }\end{array}$ & $\begin{array}{l}\text { Most of the } \\
\text { time }\end{array}$ & $\begin{array}{l}\text { All of the } \\
\text { time }\end{array}$ & Total \\
\hline Women with miscarriage & $9.8 \%$ & $5.8 \%$ & $22.2 \%$ & $63.8 \%$ & $100 \%$ \\
\hline Women without miscarriage & $64.6 \%$ & $8.1 \%$ & $16.1 \%$ & $11.2 \%$ & $100 \%$ \\
\hline $\begin{array}{l}\text { I expect my health get } \\
\text { worse }\end{array}$ & $\begin{array}{l}\text { Definitely } \\
\text { true }\end{array}$ & $\begin{array}{l}\text { Mostly } \\
\text { true }\end{array}$ & Mostly false & $\begin{array}{l}\text { Definitely } \\
\text { false }\end{array}$ & Total \\
\hline Women with miscarriage & $64.6 \%$ & $21.3 \%$ & $9.7 \%$ & $4.4 \%$ & $100 \%$ \\
\hline Women without miscarriage & $22.4 \%$ & $19.1 \%$ & - & $19.1 \%$ & $100 \%$ \\
\hline $\begin{array}{c}\text { I am as healthy and } \\
\text { active as anybody }\end{array}$ & $\begin{array}{c}\text { Definitely } \\
\text { true }\end{array}$ & $\begin{array}{l}\text { Mostly } \\
\text { true }\end{array}$ & Mostly false & $\begin{array}{l}\text { Definitely } \\
\text { false }\end{array}$ & Total \\
\hline Women with miscarriage & $20.4 \%$ & $2.6 \%$ & $29.4 \%$ & $47.6 \%$ & $100 \%$ \\
\hline Women without miscarriage & $64.3 \%$ & $29.0 \%$ & $3.7 \%$ & $2.7 \%$ & $100 \%$ \\
\hline My health is excellent. & $\begin{array}{c}\text { Definitely } \\
\text { true }\end{array}$ & $\begin{array}{l}\text { Mostly } \\
\text { true }\end{array}$ & Mostly false & $\begin{array}{c}\text { Definitely } \\
\text { false }\end{array}$ & Total \\
\hline Women with miscarriage & $20.1 \%$ & $6.1 \%$ & $28.6 \%$ & $45.2 \%$ & $100 \%$ \\
\hline Women without miscarriage & $65.7 \%$ & $11.1 \%$ & $5.1 \%$ & $18.1 \%$ & $100 \%$ \\
\hline
\end{tabular}

Findings revealed that women with miscarriages have less well-being and severe emotional problems causing interference in relation with family and friends (58.4\%), feeling worse or poor health condition (47.26\%), feeling nervous $(59.4 \%)$, feeling continuous pain $(65.4 \%)$, lack of cheerful mood $(63.8 \%)$ as compared to women without miscarriages. Females without miscarriages feel excellent health $(65.7 \%)$ while $53.8 \%$ reported no emotional problem with family and friends, having cheerfulness $68.6 \%$ and $64.3 \%$ feel healthy and active.

In our study, women without miscarriages scored high on QOL (Mean= 544.9) than the women with miscarriages (Mean $=383.3$ ), with significant mean differences (t-value $=11.75, p=.000$ ) 


\section{DISCUSSION:}

Depression emerges when fetal loss converted into excessive sadness, and grief. Most of the women losses hope to give birth to their next child and it seems very difficult to them to move forward in their normal daily routine life. The results show that the level of depression is relatively high in the women who had miscarriages. Depression emerges when fetal loss converted into excessive sadness, and grief. Research literature proves that in earlier weeks of fetal loss women feel more depressive symptoms, mostly sadness and weeping, loss of hope and feeling of worthlessness, these all indicating minor depression ${ }^{[16,18]}$.

It has been proven that there is positive correlation between depression and miscarriage ${ }^{[12,16]}$. In the present study most of women gave the symptoms of major depression because there are more than 4 or 5 symptoms that met the criteria of major depression for certain period of time. A study on Irani females with miscarriages and healthy females was conducted to assess depression and emotional wellbeing. Results indicated presence of least wellbeing and high depression in women with miscarriages ${ }^{[12]}$.

In the study we have also measure the quality of life of subjects. The results have confirmed that perceived quality of life is significantly different between the women with miscarriages and the women without miscarriages and these findings are similar to a study conducted at Islamabad in which significant correlation demonstrated between self-acceptance and life-satisfaction among unhealthy women ${ }^{[1,20]}$. Quality of life found in a decreased manner in women with miscarriages. Children gave a purpose and meaning in life to a mother, generally pregnancy adds hope in a mother to be ${ }^{[21]}$. Loss of baby or miscarriage is certainly a sudden shock for any mother and it is very hard to bear that pain and grief. In these time support of family, especially spouse is highly needed ${ }^{[22]}$. Women with miscarriages have low emotional functioning which is an important component of quality of life scale and human psychology ${ }^{[23]}$. Moreover, social functioning and physical functions are also affected in most of such women. In previous studies the quality of life was found associated not only with miscarriages but with other psychological disorders too. The results showed that perceived low quality of life can develop other disorders if not increased, because it gives rise to hopelessness and least interest in life ${ }^{[24]}$. The present study focuses on quality of life with miscarriages, so it is confirmed that miscarriages are one major reason for perceived low quality of life in women. Perceived low quality of life affects not only the physical wellbeing but also the mental health of individuals, so women with miscarriages start perceiving things negatively, and their believes for themselves change to inferiority, which affect their social functioning and behaviors negatively. A study was conducted in Dow University of Medical and Health Sciences Karachi regarding paternal factors in spontaneous first trimester miscarriage in which it is described that paternal age more than 35 years is an independent risk factor in spontaneous first trimester miscarriages ${ }^{[20,24,25]}$.

\section{CONCLUSION:}

Women with miscarriages possess low level of quality of life and also have the moderate and severe level of depression compared with the women without miscarriages. Depression is increasing rapidly in the women who lose their fetus. Depression is mostly associated with sadness and grief and it tend to decrease their interest in life activities and they feel emotionally detached and loneliness as compared to other healthy women that are without miscarriages. So, women who experience this trauma need more psychological support and care to return back to life purposefully. Therefore, it is important to provide such females psychological support, health care support and social support to get able to be involved in life again for the betterment of family and society.

\section{ACKNOWLEDGEMENT:}

Special thanks to Medical Superintendent of hospitals including their management and administration for facilitation.

JUMDC Vol. 11, Issue 4, October-December 2020 


\section{CONFLICT OF INTEREST: None}

\section{GRANT S UPPORT \& FINANCIAL DISCLOSURES: None}

\section{REFERENCES:}

1. Sapra KJ, Joseph KS, Galea S, Bates LM, Louis GM, Ananth CV. Signs and symptoms of early pregnancy loss: a systematic review. Reproductive Sciences. 2017; 24(4):502-513. Doi: $10.1177 /$ 1933719116654994

2. Gerdts C, Dobkin L, Foster DG, Schwarz EB. Side effects, physical health consequences, and mortality associated with abortion and birth after an unwanted pregnancy. Women's Health Issues. 2016; 26(1):5559. Doi:10.1016/j.whi.2015.10.001

3. Bandura A. Social cognitive theory of personality. Handbook of personality. 1999;2:154-196.

4. Wang $\mathrm{H}$, Gao H, Chi H, Zeng L, Xiao W, Wang $Y$, et al. Effect of levothyroxine on miscarriage among women with normal thyroid function and thyroid autoimmunity undergoing in vitro fertilization and embryo transfer: a randomized clinical trial. Jama. 2017; 318(22):2190-2198. Doi:10.1001/ jama.2017.18249

5. American Psychiatric Association. Diagnostic and statistical manual of mental disorders: DSM-V. 4. Washington, DC. 2013. Doi: 10.1176/appi.books. 9780890425596.dsm05

6. Nynas J, Narang P, Kolikonda MK, Lippmann S. Depression and anxiety following early pregnancy loss: recommendations for primary care providers. Prim Care Companion CNS Disord 2015;17(1). Doi: 10.4088/PCC.14r01721

7. Cullen S, Coughlan B, Mc Mohan A, Casey B. Parents' experiences of clinical care during second trimester miscarriage. British Journal of Midwifery. 2018;26(5), 309-315. Doi: 10.12968/bjom.2018.26.5.309

8. Williams \& Wilkins, Miscarriage. The John Hopkins Manual of Gynecology and Obstetrics. Lippincott Series . 2012.

9. Abdenlazim IA, AbuFaza M, Purohit P, Farag $\mathrm{RH}$. Miscarriage definitions, causes and management: review of literature. Journal of Gynecology and Obstetrics. 2017; 2(3):20-31. Doi: $10.20431 / 2456$ 0561.0203005

10. Iwanowicz-Palus G, Mroz M, Bien A. Quality of life, social support and self-efficacy in women after a miscarriage. Health and quality life outcomes. 2020:2-10. Doi: 10.21203/rs.3.rs-28515/v2

11. Campillo IS, Meaney S, McNamara K, O' Donoghue K. Psychological and support interventions to reduce levels of stress, anxiety or depression on women's subsequent pregnancy with a history of miscarriage: an empty systematic review. BMJ open. 2017;7(9):e017802.

12. Tavoli Z, Mohammadi M, Tavoli A, Moini A, Effatpanah $M$, Khedmat $L$, et al. Quality of life and psychological distress in women with recurrent miscarriage: a comparative study. Health and quality of life outcomes. 2018; 16 (1): 150. Doi: 10.1186/s12955018-0982-z

13. Abbaspoor Z, Razmju PS, Hekmat K. Relation between quality of life and mental health in pregnant women with prior pregnancy loss. Journal of Obstetrics and Gynecology Research. 2016; 42(10):12901296.Doi: 10.1111/JOG.13061

14. Volz M, Voelkle MC, Werheid K. General selfefficacy as a driving factor of post-stroke depression: A longitudinal study. Neuropsychol Rehabil. 2019;29(9): 1426-1438.

15. Klier CM, Geller PA, Neugebauer R. Minor depressive disorder in the context of miscarriage. Journal of affective disorders. 2000; 59 (1):13-21.

16. Mutiso SK, Murage A, Mukaindo AM. Prevalence of positive depression screen among post miscarriage women-A cross sectional study. BioMed Central Psychiatry. 2018; 18(1):32. dOI:10.1186/s12888018-1619-9

17. Nynas J, Narang P, Kolikonda MK, Lippmann S. Depression and anxiety following early pregnancy loss: recommendations for primary care providers. The primary care companion for CNS disorders. 2015;17(1). Doi: 10.4088/PCC.14r01721

18. Abramson LY, Seligman ME, Teasdale JD. Learned helplessness in humans: critique and reformulation. Journal of abnormal 
psychology. 1978; 87(1):49-74. DOI: 10.1037/0021-843X.87.1.49

19. Beck AT, Steer RA, Carbin MG. Psychometric properties of the Beck Depression Inventory: Twenty-fiveyears of evaluation. Clinical psychology review. 1988; 8(1):77-100. DOI: $10.1016 / 0272-$ 7358(88)90050-5

20. Iwanowicz-Palus G, Zarajczyk M, Pięta B, Bień A. Quality of life, social support, acceptance of illness, and self-efficacy among pregnant women with hyperglycemia. International Journal of Environmental Research Public Health. 2019;16(20):3941.

21. Iwanowicz-Palus G, Zarajczyk M, Pięta B, Bień A. Quality of life, social support, acceptance of illness, and self-efficacy among pregnant women with hyperglycemia. International Journal of Environmental Research and Public Health. 2019;16(20):3941. Doi:10.3390/ ijerph16203941

22. Comer RJ. Abnormal Psychology. Worth Publishers; Ninth edition. ISBN-10: 146417170X ISBN-13: 978-1464171703. 2018.

23. Brown J, Bowling A, Flynn T. Models of quality of life: A taxonomy, overview and systematic review of the literature. European forum on population ageing research. 2004:113. [Available at] http://www.ageingresearch.group.shef.ac .uk/pdf/qol.

24. Steer RA, Rissmiller DJ, Beck AT. Use of the Beck Depression Inventory-II with depressed geriatric inpatients. Behavior research and therapy. 2000; 38(3):311318. Doi:0.1016/S0005-7967(99)00068-6

25. Gul S, Khurshid M. Self-Acceptance and Life Satisfaction among Breast Cancer Patients of Islamabad. Journal of University Medical \& Dental College. 2017; 8(4):46-51.

\section{Authors Contribution:}

Parvasha Memon: Designed the study, collected the data

Lubna Ahmed Soomro: Manuscript writing, Collection of the data

Muniza Malik: Statistical Analysis and interpretation of the data and Critical revision of the article for important intellectual content

Saira Almas: Drafting of the article, Assembly of data and Critical revision of the article for important intellectual content.

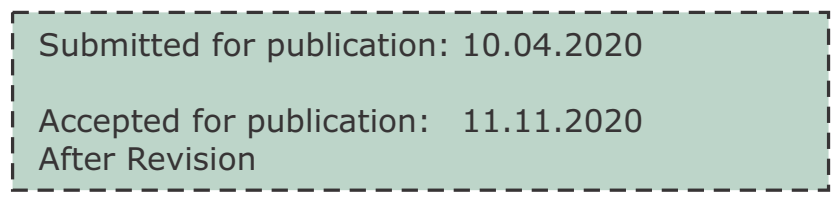

